\title{
Party Cross-carpeting in Nigeria's Fourth Republic: Cases and Causes
}

\author{
Olu Awofeso \\ Department of Political Science, Obafemi Awolowo University \\ Ile-Ife, Osun State, Nigeria \\ Paul A. Irabor (Corresponding author) \\ Department of Political Science, Obafemi Awolowo University \\ Ile-Ife, Osun State, Nigeria \\ Email: olufeso2012@yahoo.com
}

Received: July 26, 2016 Accepted: September 01, 2016 Published: September 08, 2016 doi:10.5296/jpag.v6i3.10000 URL: http://dx.doi.org/10.5296/jpag.v6i3.10000

\begin{abstract}
The study examines party cross-carpeting in Nigeria's Fourth Republic. These were with the view to investigating the effects of cross-carpeting on the country's democratic engagement. From historical antecedence standpoint, the study reveals that cross-carpeting was patterned towards ethnic/religion inclination, intra-party feud and selfish interest of the political class. Coupled with these anti-democratic tendencies, the study also found that indiscipline in political parties and lack of ideology were the major factors that determined cross-carpeting in Nigeria's Fourth Republic. Finally, the study affirms that party discipline and ideology must be strictly adhered to by political parties to check the menace of incessant cross-carpeting among political office holders.
\end{abstract}

Keywords: Political party, Cross-carpeting, Party discipline, Ideology, Intra-party conflict 


\section{Introduction}

Political parties organize the terms of elite competition, and thus offer and defend alternative choices to voting citizens. Fittingly, the popular axiom that democracy without parties is "unthinkable" finds expression in this context (Schnattschneider, 1942:1). Similarly, competition among political actors is only meaningful when it is aimed towards party institutionalization which according to O'Brien and Shomer (2013) is a function of organizational loyalty. In other words, political actors do not just contest for political power they must conform to certain generalized political imperatives. It is this structure and defining modalities for intra-party and inter-party interrelationships that enhance multi-party system in pluralist democracy.

Multiparty democracies need multiple parties, where one serves as the ruling party and others as oppositions and alternatives. Conversely, Third World countries such as Nigeria face a major and persistence problem: incessant cross-carpeting among elected political actors which tend to impede democratic consolidation. Cross-carpeting, otherwise known as party defection, party switching, floor-crossing, party-hopping, canoe-jumping, decamping, party-jumping (Malthora, 2005; Mbah, 2011; Aleyomi, 2013; Fashagba 2014) is a situation where politicians cross from one political party to the other due to myriad of reasons such as personality clash, power tussles, crisis or division within a given party, disagreement on party's position on an issue, realization of one's personal political ambition, and divergent views on the operations of a political party's philosophy or ideology (Hoeane, 2008). However, carpet-crossing have become undying attribute of party politics in the present democratic dispensation and have become frequent toward and after election periods. Periscoping from historical perspective to situate the present events, the paper identifies cases and reasons for incessant cross-carpeting in Nigeria's Fourth Republic and advances some means of tackling the menace to pave way for democratic stability.

\section{Review of Literature}

\subsection{The Concept and Functions of Political Parties}

Indeed, there is still a major disagreement among political scientist on how best to define a political party. This has led to a genre of literature on political parties which have acquired the distinctive name stasiology i.e political parties as subject (Ojo, 2008: 64). However, the point of convergence of the various definitions is anchored on the point that political party is the major institution for organizing democratic government. Max Weber (cited in Kifordu, 2011) defines political party as contending groups that struggle for political control within corporate bodies. This definition places politicians and candidate for leadership recruitment into both elective and appointive positions as principal actors and the objectives of party organization is to capture governmental powers. Similarly, Likoti (2005) posits that political party is an organized group of people with similar political aims and opinions that seek to influence public policy by getting its candidate elected to public office. The theme and context of these definitions suggests that the primary objective of political parties is to contest and win election so as to organized and dominate the organs of national leadership. Edmund Burke (cited in Ojo, 2008) defines political party "as a body of men, united, for promoting 
their joint endeavors, the national interest upon some particular principles in which they all agreed". Herbert Simon (1962) asserts that a political party is a social group with a system of interdependent activities characterized by a high degree of rational direction of behavior towards end that are objects of common acknowledgement and expectation. These definitions informed us that parties exist to serve national interest based on certain principles (ideology) and not sectional interest. Evidently, the definitions of political parties make it quite different from other social groups such as Labour Unions and other associations because of their unique features. One of such features is ideology. An ideology is basically a philosophy or set of principles that underlies a political program. It consists of the shared beliefs, attitudes, and assumptions that cause a certain group of people to come together and develop advocate specific political programs. Nnoli (2003: 177-82) observers that ideology is a very crucial aspect of political party, not only by serving as a cognitive structure for looking at society generally and providing a prescriptive formula, that is, a guide to individual action and judgment, but also as a powerful instrument of conflict management, self-identification, popular mobilization and legitimization. The ideologies of a political party are put down in writing called party manifesto (or blueprint or action plan). The manifesto is a statement of the goals and principles the party promises to pursue if voted into power. As a contract with voters, the manifesto spells out the party's perception of the country's problems and states how the party proposes to address problems and help achieve the collective aspirations of the nation if elected. Another essential characteristic of a political party is the membership base. A political party recruits people who are committed to its ideology and principles and who will be able to participate in party governance, policy formulation, and campaigning. Members of parties are able to shape the ideology and policies of their parties (Webb et al, 2002).

Giving this peculiarity of political parties from other social groups, parties are expected to perform some roles, without which democracy would be impracticable. One major role expected of any political party is the task of political recruitment and education. The centrality of this function lies in the fact that it is directly connected with fulfillment of the common aim of all parties. That is, the aim of fielding candidates for election and capturing or exercising political power either singly or in cooperation with other parties (Yaqub, 2002: 164). Related to the task of recruitment and education is the role of political parties as socializing agents. Political socialization has been conceived as all formal and informal explicitly or nominal political learning at every stage of the life cycle that affects political behaviour, such as learning of politically relevant social attitudes and the acquisition of politically relevant personality characteristics (Babawale, 1999).

\subsection{On the Concept of Cross-carpeting}

Since parties are the primary mechanism linking voters and politicians in modern democracies, committed and stable party activists enable cast appropriate ballots (Omilusi, 2013). Moreover, it should be noted that the phenomenon of cross-carpeting is no respecter of the age of a democracy. It occurs both in the established and in new democracies (Chang, 2009). However, the frequency of its occurrence varies from country to country. For instance, Evans and Hadley (2010) argued that only 20 switches took place in the American Congress 
from the 1940s to the 1990s. By contrast, defection is reported very frequently in most African new democracies. The term 'cross-carpeting' has been used interchangeably with concepts like party defection, party switching, floor-crossing, party-hopping, canoe-jumping, decamping, party-jumping (Malthora, 2005; Mbah, 2011; Fashagba 2014). In his work, Chang (2009) used the term 'political defection' in place of cross-carpeting. He defines political defection as a situation in which a legislator switched from his original party to run either under another party or as an independent candidate. Relatedly, Blunt (1964) defines party switching in place of cross-carpeting as any situation in which a member of a legislature who had been elected on a certain party platform changed his political allegiance before a next general election. In this regard, political party defectors are usually regarded as political prostitutes without political principle, morality, conscience and lacking in political ideology to champion the cause of leadership for the wellbeing of the society and political development of the country.

Different reasons have been advanced for the occurrence and prevalence of cross-carpeting in Africa. One reason is the nature of party formation. Party formation is often driven by political careerism rather than ideology. According to Omotola (2009), 'the role of ideology in party formation and competition tend to be weak in African third-wave democracies'. Personal ambition and ethnic loyalty, as opposed to social and economic issues, tend to drive Africa's political parties (Rakner and Walle, 2009:115). The deprivation that opposition politics might engender often made it unwise for politicians to remain in opposition parties (Fashagba, 2014). This is perhaps so because the party in power often discriminated against the opposition. Thus, owing to the winner-takes-all nature of African politics, political opponents usually had to choose between crossing the carpet to join the ruling party or suffer exclusion, repression and lack of access to resources. Also, Cross-carpeting from opposition parties to the ruling party explains the emphasis on the primacy of political power. This is because the possession of state power leads directly to economic power, and who hold positions in the power structure determine the location and distribution of economic resources and political rewards. Similarly, patronage politics is also a motivation for cross-carpeting. In a political system where importance is attached to patronage or perks, politicians will most probably switch parties in the direction of the dispenser of the patronage. In such political systems, power relations among groups and between government and the governed is anchored on and shaped by access to state resources, facilitated by those who control the sharing (Desposato and Scheiner, 2008).

\section{Cross-carpeting in Nigeria: History, Cases and Causes}

In the pre- independence and post-independence periods, (1960-66) some of the factors that greatly influenced cross-carpeting included ethnic affiliation and religion preferences (Okpu, 1985; Osaghae, 2000). For instance, in 1951 when the first cross-carpeting episode occurred in Nigeria, the Yoruba members of the National Council for Nigerian and the Cameroon (NCNC) were lobbied to cross over to the Action Group (AG) to stop Dr. Nnamdi Azikiwe, an Igbo man, from becoming the premier of Western Region. In the First Republic (1960-1966), personality rivalries between factions and members of leadership of the parties exert a great influence on cross-carpeting among party members in Nigeria. A case in point 
was the personality clash between the former Premier of the defunct Western Region of Nigeria, Chief Ladoke Akintola and Chief Obafemi Awolwo. Kayode could vividly recounts:

Having lost the Federal election to the defunct Nigerian National Democratic Party (NNDP), Chief Awolowo wanted to ally with the East (United Progressive Grand Alliance) while Akintola wanted to ally with the North (Nigerian National Alliance). It could be argued that the bitter fight that took place between the two statesmen and their respective supporters throughout the early ' 60 's led to division within the Action Group and its eventual splitting into separate and distinct parties and the unrestrained brutal violence that was unleashed by both sides against one another led directly to the first coup d'etat of January $15^{\text {th }} 1966$ (Kayode, 2013).

In the same way as it happened between Akintola and Awolowo, Dr Nnamdi Azikiwe of the NCNC and Dr Kingsley Mbadiwe had an occasion to fall apart in their political relationship which led to Mbadiwe's formation of the Democratic Party of Nigeria Citizens (DPNC), which sought a working relationship with the Action Group at the Federal Elections in 1959 (Mbah, 2011).

By the Third Republics, money politics and political patronage had been introduced into Nigeria's body politics. Since every public office-holder uses the state power for that purpose, cross-carpeting or defection becomes inevitable from this process, since the state has become a "means of production" and a "means of primitive accumulation" (Ekekwe, 1986; Iyayi, 1986). Consequently, party membership was either retained or changed according to how easy the members perceived their elections to be in the parties. Cross-carpeting of this secenario was that of Chief Akin Omoboriowo who was elected as the Deputy Governor of Ondo State under the platform of the party Unity Party of Nigeria but left the party to the National Party of Nigeria to contest as it gubernatorial candidate (Sodeine, 2009).

These anti-democratic activities, coupled with the exigencies in the formation of parties in the return to democratic rule in 1999 - a product of military fiat- gave birth to indiscipline and gangsterism in politics. Thus, with the problems that accompanied the earlier periods, Fourth Republic political parties seem to be bereft of party discipline and ideology. Party indiscipline refers to the violation of the entrenched fundamental principles, rules and regulations guiding the conduct or behaviour of every member of a political party at all times and any deviation from these principles, rules and regulations ought to be punished accordingly, irrespective of whoever is involved (Oviasuyi 2006). Studies have provided examples of actions of indiscipline in political parties in Nigeria to include: repeated breach of the party constitution, unilateral funding of parties, the superiority influence of the individual over the party, godfatherism etc (Thovoethin, 2004; Oviasuyi 2006; Omilus, 2013). In the All Progressive Congress for example, it is believed that Bola Ahmed Tinubu, a National Leader of the party dictates and directs the party affairs (Oketola and Falodi, 2015). This is evident as candidates who emerged as the party flag-bearer in election and party executives always seek his consent and support for such position. A chronicle of cross-carpeting of this scenario is that of the former Vice President, Atiku Abubakar. After a running battle with the former president Olusegun Obasanjo, he defected to the then Action Congress where he contested the 
presidential elections (Mbah, 2011). Following the opposition of the PDP party leaders in Edo State, Senator Ehigie Uzamere (Edo-South) defected to the Action Congress of Nigeria before the 2011 elections, and was subsequently re-elected (Independent National Electoral Commission, 2011; Vanguard, 2011). 2011). In effect, the powerful individuals, with overwhelming control over the party at the federal and state levels, determined who will be nominated and any candidate opposed by the powerful politicians would be denied nomination.

The political calculation in the country took a dramatic turn by 2013 with the formation of the All Progressive Congress (APC) through the merging of four political parties- Action Congress of Nigeria (ACN), All Progressive Grand Alliance (APGA), All Nigerians Peoples Party (ANPP) and Congress for Progressive Change (CPC) - formed just to garner more supporters over the Peoples Democratic Party in the build up to the 2015 general elections (Joseph, 2014), which also coincide with the formation of New PDP (led by a former leader of the party, Kawu Baraje). This development led to the defection of five former PDP governors- Murtal Nyako (Adamawa); Abdulfatah Ahmed (Kwara), Rabiu Kwankwaso (Kano), Aliyu Wammako, (Sokoto) and Chibuike Amechi (Rivers), to the APC ahead of the 2015 general elections. Also to cross-carpet to the APC is the governor of Imo State, Rochas Okorocha, from the All Progressive Grand Alliance and the eleven PDP senators; Senator Bukola Saraki (Kwara Central), Umaru Dahiru (Sokoto South), Magnus Ngei (Rivers South), Wilson Asinobi (Rivers West), Bindawa Muhammed (Gombe Central), Aisha Jummai (Taraba North), Mohammed Ali (Borno South), Mohammed Shaba (Kwara North), Abdulahi Adamu (Nasarawa West) and Ibrahim Abdullahi (Sokoto East), as well as thirty-seven members of the House of Representatives who cross-carpeted from the PDP to APC (Ebere, 2014).

Moreover, with the mantle of political power turning to the APC after the 2015 general elections, politicians continued to defect to the party in a bid to further their political career. Leading the set of defectors is a former National Legal Adviser of the PDP and gubernatorial candidate party in the 2012 election in Ondo State, Chief Olusola Oke, who led a contingent of the PDP members, mainly from the South Senatorial District of the state, to decamp to the APC. Olusola Oke (cited in Ohia, 2015) said:

I resisted the wind of change that was blowing, until it was almost trying to blow me out. Now, I have surrendered; I can resist no more, and I have come. I have come over, not because the PDP lost election, I have come over because the wind of change that is blowing across Nigeria must blow in Ondo State.

Essentially, parties are formed by individuals that share the same political ideology, that hold a common vision and mission statement (Ojukwu and Olaifa, 2011). Empirical studies have revealed that Fourth Republic political parties in Nigeria are composed of persons with different ideologies who do not only misunderstand themselves but are regularly feuding (Omotola, 2009; Mbah, 2011). Thus, while Omotola (2009) is of the opinion that this faulty origin of political parties in Nigeria is responsible for the party's ideological barrenness, it is emphasised further that poverty of ideology is significantly accountable for the prevailing 
cross-carpeting of the Fourth Republic. For instance, virtually all political parties in Nigeria seem to have one internal crisis or the other. Sometimes these crises snowballed into full scale conflict, leading to division and fictionalization within the party. The All Progressives Congres (APC) is presently toeing the line of the Peoples Democratic Party (PDP) with the outcome of the party convention that saw the election of national leaders of the party. The fact that one of the contestants for the position of party chairman who was formerly of the PDP, Tom Ikimi returned to PDP lends credence to this (Nwanegbo et. al, 2014). More so, hardly had the APC won the 2015 presidential election, its members in the National Assembly were involved in leadership crisis.

\section{Implications of Cross-carpeting in Nigeria's Fourth Republic}

Cross-carpeting no doubt has telling effects on the process of consolidating democracy, especially when it affects state and federal elected political office holders. This trend is fast making caricature of democracy in the Fourth Republic and seriously belittles the spirit of opposition parties. Until the recent formation of the APC in 2013 strengthened by the defections of five aggrieved governors and other parliamentarians from the then ruling PDP, cross-carpeting right from the inception of the Fourth Republic had always been in the direction of the ruling party. A development that had led to the further fragmentation of opposition parties where defectors emanated from. This often breeds the emergence of new political parties that lack strength and focus to compete reasonably in the polity. In other words, incessant cross-carpeting weakens opposition parties which have a telling effect on democratic consolidation in Nigeria.

Frequent cross-carpeting among the political actors leaves the electorate with no alternatives to choose from when it comes to ideological bloc. As such, the character composition of parties is no more different- the only difference is of nomenclatural relevance (Ilo, 2015). Consequently, parties developed ideologies only to win election and form new government. This gives the ruling party opportunities to operate without constructive criticism. Moreover, Hoeane (2008) argues that in extreme cases of cross-carpeting where number of public representatives who defected are significantly high, such shifts of allegiance have led to the collapse of democratically elected governments, such as in Lesotho in 1997. As such, cross-carpeting of elected office holders who do not resign the first platform for coming to political position do not add value to the process of democratic consolidation.

Another twist that further weakens the consolidation of democracy is the motivation for cross-carpeting among elected political actors that lack philosophical backup. This tends to promote money-bag politics rather than ideological oriented political parties. According to the News Magazine of February 2014, a "mouth-watering" offers of money were outlined for the legislators that cross-carpeted to the APC in the build up to 2015 general elections. According to the report, the then ruling PDP was said to have promised US\$2 million to each senator who returns to the PDP, US\$ 1 million to each member of the House of Representatives and US\$ 10 million to each 'leader' who abandoned the APC for the PDP. Although, this is considered a rumour in some quarters, one cannot completely dispel issues like this in any polity that is not ideologically driven, where possession of political power is 
viewed directly as economic empowerment. Arising from the above, building strong opposition parties under such circumstances becomes very difficult; hence consolidating democracy in such polity becomes a mere wishful thinking.

\section{Conclusion}

Arising from the popular perceptions of the scholars was that, while cross-carpeting is a feature of multiparty democracy like Nigeria, it can only be relevant when elected office holders respect the "rules of the game" that guide cross-carpeting. Therefore, indiscriminate cross-carpeting by the political actors is antithetical to democratic stability. The study gave the understanding that discipline and definite ideology must be held with seriousness by the parties. This will curtail incessant cross-carpeting that have become the hall mark of Nigerian politics.

\section{Recommendations}

At the heart of cross-carpeting and democratic consolidation as the study has rightly pointed out, is the attempt to eschew indiscipline and inculcate ideological principle in Nigeria's political party. These recommendations were made for effective management of the arising development.

First, given the danger of democratic consolidation posed by the present stronghold on parties by the elites, parties need to be re-organized on the principle of all-inclusiveness rather than exclusion. This means that issues of monopolization of party decision making process, lack of internal democracy and indiscipline in parties have to be tackled.

Another pre-requisite to combat incessant cross-carpeting is to de-emphasize the excessive premium placed on political power. When politics becomes less lucrative, ideology will begin to gain popularity across the polity. This will keep political practitioners back on the track and guide against incessant cross-carpeting.

Based on the findings of this work that cross-carpeting is usually triggered by intra or inter party conflict, it is recommended that political parties should be re-engineered from mere institutions for acquiring political power to effective institutions that are capable of mediating and reconciling interests and conflicts.

\section{References}

Agbaje, A., Adejumobi, S. (2006). Do votes count? The travail of electoral politics in Nigeria, Journal of Africa Development, 33(3), 25-44.

Aleyomi, M. (2013). Election and Politics of Party Defection in Nigeria: A Clue from Kogi State. Covenant University Journal of Politics and International Affairs (CUJPIA), 1(1), 72-84.

Babawale, T. (1999). Political Culture and Political Socialization. In R. Anifowoshe and F. Emenuo (Eds.), Elements of Politics. Lagos, Nigeria: Sam Iwanusi Publications, pp. 210-225. 
Blunt, M. (1964). Carpet crossing, Parliamentary Affairs, 18 (1), 82-91.

Chang, A. (2009). Reelection Incentives and Defection: Party switching in the Japanese Liberal Democratic Party. Japan: Institute of Political Science, Academia Sinica.

Desposato, S. and Scheiner, E. (2008). Governmental Centralization and Party Affiliation: Legislator Strategies in Brazil and Japan. American Political Science Review, 102 (4), 509-524.

Ebere, N. (2014, September 2). Curtailing Cross-carpeting by Elected Politicians. National Mirror.

Ekekwe, E. (1986). Class and State in Nigeria. Lagos: Longman.

Evans, K. and Hadley, N. (2010). Party switching and the Goals of Members in the US Congress: The cases of Arlen Specter, Olympia Snowe, and Susan Collins, Paper prepared for WPSA, San Francisco, CA.

Fashagba, J. (2014). Party Switching in the Senate under Nigeria's Fourth Republic. The Journal of Legislative Studies, 20(4), 516-541.

Herbert, S. (1962). Comments on the Theory of Organization. A Journal on American Political Science Review, Vol.46, 30.

Hoeane, T. (2008). Floor-Crossing in South Africa: Entrenching or Undermining Democracy? South African Journal for Political Science and Public Administration, 27(2).

Ilo, J. (2015, July 24). The Tragedy of Defections and Valueless and the Nation's Political Party at Large. Premium Times.

Independent National Electoral Commission. (2011). Senatorial Election Result. Retrieved July 25, 2015, from http://www.inecnigeria.org/?downloaddoc-Result-of- $9^{\text {th }}$-april-2011-senatorial district-election Iyayi, F. (1986). Primitive Accumulation of Capital in a Neo-Colony: The Nigerian Case. Review of African Political Economy, No.35.

Joseph, P. (2014). Incessant Defection among Politicians Worries Lawyer. Daily Post, February 17, p.18.

Kayode, F. (2013). Between S.L Akintola and Obafemi Awolowo. Premium Times, Retrieved Thursday, April 14, 2016.

Likoti, F. (2005). Investigating Intra-Party Democracy in Lesotho: Focus on Basutoland Congress Party and Basuto National Party, EISA Occasional Paper Series, NO 39.

Malthora, G. C. (2005). Anti-defection Law in India and the Commonwealth. New Delhi: Metropolitan Book Co Pvt Ltd.

Mbah, P. (2011). Party defection and democratic consolidation in Nigeria, 1999-2009. Afro-Asian Journal of Social Sciences, 2(3), 1-21. 


\section{Macrothink}

Journal of Public Administration and Governance ISSN 2161-7104 2016, Vol. 6, No. 3

Nnoli, O. (2003). Introduction to Politics (Revised 2nd Edition). Enugu: PACREP.

Nwanegbo, J., Odigbo, J. and Nnorom, (2014). Party Defection and Sustenance of Nigerian Democracy. Global Journal of Human Social Science, 14(6), Version 1.0.

O'Brien, D., Shomer, Y. (2013). Legislators Motivations, Institutional Arrangements, and Challenges in Partisan Affiliation: A Cross-National Analysis of Party Switching. Legislative Studies Quarterly, 38(1).

Okpu, U. (1985). Inter-party Relations in Nigeria, 1979-1983. African Spectrum, 20(2), 191-205.

Ojo, E. (2008). Challenges of Sustainable Democracy in Nigeria. Ibadan: John Achers.

Ojukwu, C. and Olaifa, T. (2011). Challenges of internal democracy in Nigeria's Political Parties: The Bane of Intra-party Conflicts in the Peoples Democratic Party of Nigeria. Global Journal of Human Social Sciences, 11(3), Version 1.0.

Omilusi, M. (2013). Democracy and Governance in Nigeria: Key Issues and Challenges. Akure: Adex Printing Press.

Omotola, J. (2009). Nigerian Parties and Political Ideology. Journal of Alternative Perspectives in the Social Sciences, 1(3), 612-634.

Osaghae, E. (2000). Crippled Giant: Nigeria since Independence. London: Hurst.

Oviasuyi, P. (2006). Indiscipline in Political Parties: Bane of Democratic Consolidation and Good Governance in Nigeria. Educational Research Quarterly, 30(1).

Rakner, L and Walle, N. (2009). Democratization by elections? Opposition weakness in Africa. Journal of Democracy, 20(3), 108-121.

Schnattschneider, E. (1942). Party Government. New York: Farrar and Rinehart.

Sodeine, G. (2009). No Regret for my Past Roles in Politics- Omoboriowo. Daily Independent.

Thovoethin, P. (2004). Godfatherism and Democratic Consolidation in Nigeria: Issues and Perspectives. In M. Dukor, A. Leigh and H. Paulin (Eds.), Godfatherism in Nigeria's politics.

Vanguard Newspaper. (2011). How PDP Dominated the Sixth Senate. Retrieved June 15, 2015, from www.vanguardngr.com/2011/04/how-pdp-dominated-the-sixth-senate.

Webb, D., David M. F. and Holliday, L. (2002). Political parties in advanced industrial democracies. Oxford: Oxford University Press.

Yaqub, N (2002). 'Political Parties in the Transition Process' in Onuoha, Browne and Fadakinte, M. M. (eds.), Transition Politics in Nigeria, 1970 - 1999. London: Malthouse Press limited pp 118 - 134. 


\section{Macrothink}

\section{Copyright Disclaimer}

Copyright for this article is retained by the author(s), with first publication rights granted to the journal.

This is an open-access article distributed under the terms and conditions of the Creative Commons Attribution license (http://creativecommons.org/licenses/by/3.0/). 